\title{
Immunogenic Responses of Effective Vaccine Candidates against Streptococcus Agalactiae in Ruminants
} \author{
Azmi ML ${ }^{4}$ and Zamri-Saad ${ }^{4}$ \\ ${ }^{1}$ Department of Veterinary Clinical Studies, Faculty of Veterinary Medicine, Malaysia \\ ${ }^{2}$ Department of Farm and Exotic Animals Medicine and Surgery, Malaysia \\ ${ }^{3}$ Department of Veterinary Medicine, Faculty of Agriculture and Veterinary Medicine, Malaysia \\ ${ }^{4}$ Department of Veterinary Pathology and Microbiology, Faculty of Veterinary Medicine, Malaysia \\ ${ }^{5}$ Department of Veterinary Medicine, Faculty of Veterinary Medicine, Nigeria \\ ${ }^{6}$ Department of Tropical Agriculture and food security, Malaysia \\ ${ }^{7}$ Department Livestock and Dairy Development Baluchistan, Pakistan \\ ${ }^{8}$ Department Livestock and Fisheries Veterinary Research and Diagnosis, Pakistan \\ ${ }^{9}$ Department of Medical Laboratory Science, Faculty of Allied Health Sciences, Nigeria
}

Lawan $A^{* 1,5}$, Jesse FFA ${ }^{1,2}$, Odhah MN ${ }^{1,3}$, Bala JA ${ }^{4,9}$, Arsalan ${ }^{6,7}$, Bhutto $\mathrm{KR}^{1,8}$, Abraham GA ${ }^{1,2}$, Wahid AH$^{1}$, Mohd

*Corresponding author: Lawan A, Department of Veterinary Clinical Studies, Faculty of Veterinary Medicine, Malaysia.

Received Date: December 11, 2018

Published Date: January 24, 2019

\begin{abstract}
Streptococcus agalactiae ( $S$. agalactiae) is a catalase negative, facultative anaerobic, Gram-positive and important bacterium predominantly linked with mastitis in cows and ewes. Albeit GBS has a vulnerable proclivity to numerous antimicrobial agents, the residuary of drug levels has a remarkable influence on milk prominence and on public health. An ideal and potent GBS vaccine should stimulate systemic and mucosal immunity. The physiognomies of several adjuvant of vaccine formulations that possess the capability of provoking collective immunity ensuing immunization revealed that dendritic cells could perchance serve as effective antigen presenting cells (APC) stimulating enhanced and collective immunity. For interpretation of the existing evolution in transcriptomics, proteomics, metabolomics, and metagenomics exploration, some wide-ranging assessments of the enormous proteins and genes which were made known by a microorganism is highly accessible presently. As well, existing is a remarkable expectation in this growing expertise by understanding the bacteria and host relationship. For this reason, the prosperous facts may perhaps enormously pledge to the development of effective vaccines against $S$. agalactiae contagions in hominids and faunas. Hence, this review emphasis and elucidates on the standard up-to-date procedures consisting of transcriptomics, proteomics, metabolomics, and metagenomics techniques and their importance on immunogenic responses of effective vaccine candidates against $S$. agalactiae in ruminants.
\end{abstract}

Keywords: Immunogenic; Vaccines; S agalactiae; Ruminants

\section{Introduction}

Streptococcus agalactiae (S. agalactiae) fall under the class of Lancefield group B Streptococci (GBS); is a catalase negative, $\beta$-hemolytic, non-motile, facultative anaerobic, Grampositive, opportunistic and important bacterium frequently and predominantly associated with mastitis in cows and ewes [1-4], and

it persists for a long-drawn-out period [5] which is an economically essential issue in dairy cow industries all over the universe [6]. Furthermore, $S$. agalactiae is a significant humanoid bacterium which prompt aggressive illness in an infant less than four weeks old, aged individuals and gravid women [4,7]. The studies on the 
prevalence of $S$. agalactiae in cattle have been described for several countries [5], in 2013, the international production of milk was about 782,000,000 tonnes [8]. Milk production is universally hindered by a singular most important factor; mastitis [8]. Even though GBS has a vulnerable proclivity to numerous antimicrobial agents, the residuary of drug levels has a tremendous influence on milk prominence and on public health [9]. A recent study exemplified that an on-farm culture (OFC) method that is used in the therapy of mastitis could undoubtedly fail to be affordable in numerous situations, specifically, not cases that involve Grampositive bacteria which accounts for more than twenty percent of all clinical cases of mastitis [10]. An outcome of the research also emphasised on the ethical impasse pertaining to the decreased usage of antimicrobial agents for mastitis management because it would perchance relate to economic forfeiture and inferior cattle wellbeing for numerous cases [10]. Under tropical conditions, the assessed problems of the combined economic influence of mastitis in relation to herd population including the clinical and subclinical mastitis has been colossal $[6,11,12]$. Intermittently, $S$. agalactiae is predominantly connected with infection in numerous hosts, for instance horses, camels, sheep, goats, dogs, cats, fish, frogs and chickens $[2,13,14]$. An ideal and potent GBS vaccine should engender systemic and mucosal immunity. Immunization of mice through nasal, oral, vulva and rectal itineraries, with combination of cholera toxin B and GBS type III subunit "GBS III CPS-rCTB" stimulated systemic and local immunity after mucosal vaccination, the Cholera toxin (CT) was incorporated as an adjuvant [15]. The conjugated CPS inoculated through the nasal, oral, vulva and rectal itineraries was enormously potent at provoking both mucosal and systemic responses to GBS III CPS more than the non- conjugated CPS; thus, CPS explicit immunity in different biological structures remained reliant on the itinerary of vaccination. Largely, maximum concentrations of immunoglobulins $A$ and $G$ produced in the zones of the conjugate subjection. Therefore, in the lungs the nasal immunization stimulated peak anti-CPS IgA and IgG antibody concentrations, while oral inoculation in the intestinal region and vulva immunization prompted maximum antibody concentrations in the vulva $[15,16]$. Current information incriminates interleukin-17 response of a host to infection and a conceivable intermediary for the removal of GBS $[17,18]$, and it has been shown that mice deficient of both antibody generation ( $\mu \mathrm{MT})$ or neonatal Fc receptor takes a flaw for the removal of GBS from the vulva and that mucosal vaccination coordinates the removal of infection [17].

Rectal immunization was prime to some of the itineraries in prompting elevated antibody concentrations in the rectal region. The itineraries of mucosal immunization likewise kindle far-flung antibody responses to CPS. Immunization in the rectum produced elevated specific IgA concentrations in the intestine and vulva, and oral inoculation stimulated an elevated specific IgA concentration of rectum and lungs $[15,16]$. All four itineraries of immunization with the conjugate stimulated correspondingly elevated concentrations of IgG antibodies against CPS. Nasal immunization of dissimilar dosages of conjugated CPS was not able to produce a substantial effect on the anti CPS specific humoral response. Nasal vaccination stimulated heightened antibody responses when a single dosage of the conjugate was apportioned and inoculated on three sequential days relative to the inoculation of the complete dosage in a single instance [15] likewise intranasal stimulation of goats with killed $P$. haemolytica causes cellular and humoral responses [19].

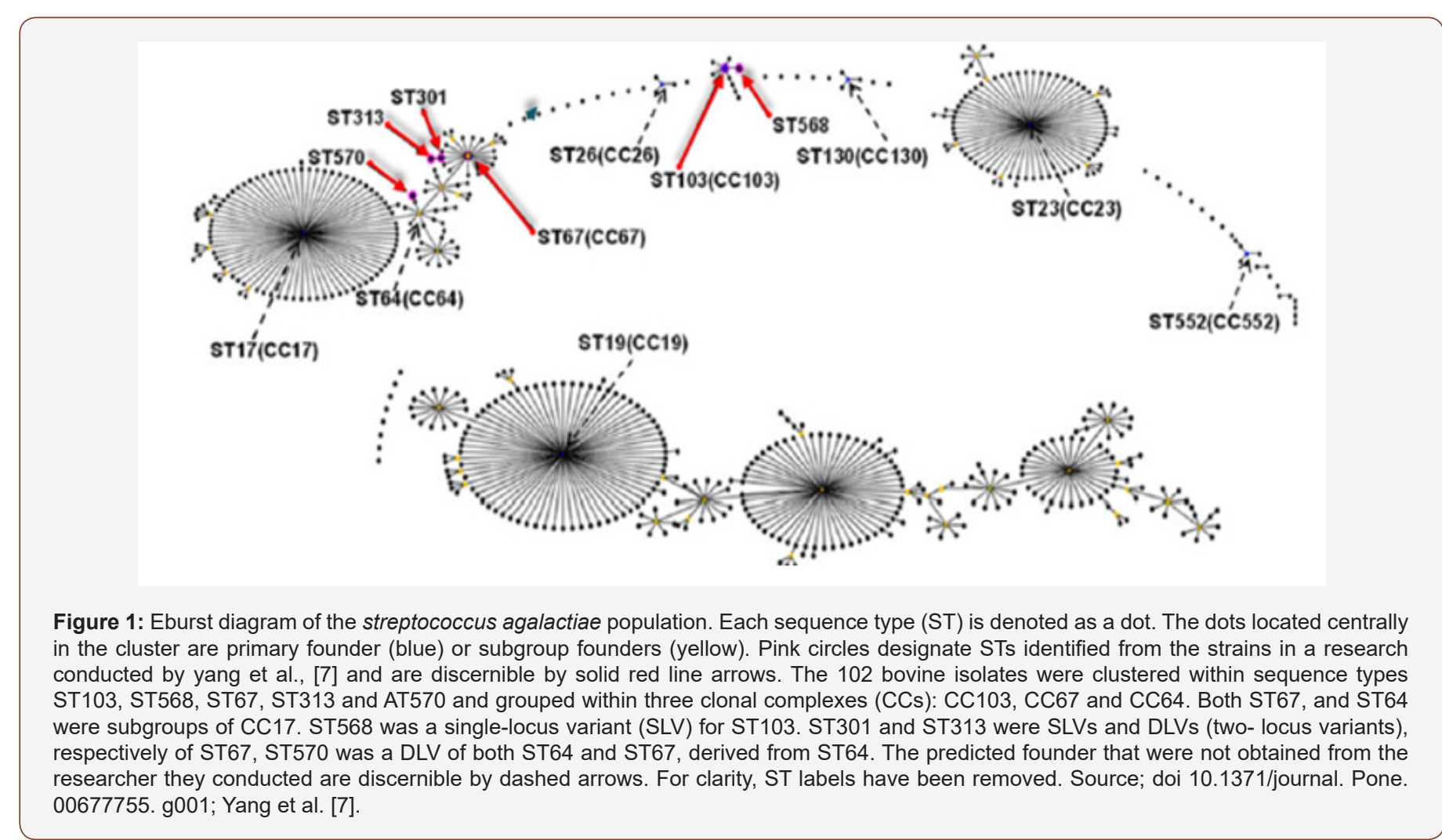

Citation: Lawan A, Jesse FFA, Odhah MN, Bala JA, Arsalan M, etal. Immunogenic Responses of Effective Vaccine Candidates against Streptococcus Agalactiae in Ruminants. Arch Animal Husb \& Dairy Sci. 1(2): 2019. AAHDS.MS.ID.000509. DOI: 10.33552/AAHDS.2019.01.000509. 
The genomics assortment of $S$. agalactiae of bovine with human pedigrees were evaluated using a wide-ranging genomic method, comprising of Pulsed-field gel electrophoresis typing (PFGE), multilocus sequence typing (MLST), Random Amplification of Polymorphic DNA (RAPD), and the ribotyping [2]. Former researches on genomic interactions established that bovine and human strains have their place in genetically diverse clusters with inadequate interspecies spread [2] otherwise they are from common source [2,5]. PFGE and MLST (Figure 1 \& Table 1) are dual genotype approaches employed to describe and differentiate specific clones amongst GBS isolates [7,20-21]. MLST is an explicit sequence based and a consistent typing contrivance, consenting juxtaposition of the gene dissemination regarding dissimilar isolates assembled from all geographical zones and the structure of the isolates are additionally investigated $[7,22]$. There is a data of 583 S. agalactiae sequence types (STs) classified and provided on the repository website of MLST in May 2012 (http://pubmlst.org/ sagalactiae/), even though data on bovine strains up to this time is inadequate [7].

Table 1: Relatedness of 21 group B Streptococcus (GBS) strains based on Neighbouring joining and concatenated multilocus sequence typing data obtained from 7 house-keeping gene(s) and cps capsule serotypes/ genotypes.

\begin{tabular}{|c|c|c|c|}
\hline $\begin{array}{c}\text { Sequence Type } \\
\text { (ST) }\end{array}$ & No. of Strains & $\begin{array}{c}\text { cps Genotype } \\
\text { (n) }\end{array}$ & $\begin{array}{c}\text { Clonal } \\
\text { Complex (CC) }\end{array}$ \\
\hline ST-1 & 8 & cps5 (8) & CC-1 \\
\hline ST-19 & 1 & cps (1) & CC-19 \\
\hline ST-182 & 1 & cps (1) & CC-19 \\
\hline ST-8 & 1 & cps1b (1) & CC-12 \\
\hline ST-22 & 2 & cps2 (2) & \\
\hline ST-198 & 1 & cps2 (1) & \\
\hline ST-88 & 2 & cps2 (2) & CC-23 \\
\hline ST-23 & 5 & cps1a (4), cps3 & CC-23 \\
\hline
\end{tabular}

Source: Manning et al., 2010; Mahalanobis distance $=0.001$.

Conversely, other studies expounded on the isolates of human and bovine pedigrees that are of similar genetic structure [2,23]. A study also indicated that intensified regularity of bovine exposure was considerably linked to human infection hence its zoonotic origin [21]. In the burgeoning of GBS vaccine to fend off mastitis of ruminants would necessitate a comprehension of the serotypes spread amongst isolates from cows [9,24]. On the other hand, by conventional serotyping numerous GBS from cows are nontypeable [9]. In a former study, serotypes were established using sequence and PCRe variants of the section of cpsE-cpsF-cpsG at the gene of capsular polysaccharides to classify GBS molecular serotypes [9]. Capsular serotyping is an established technique employed for S. agalactiae in epidemiological researches. Presently time, only 10 serotypes were established of $S$. agalactiae CPS, have been classified and acknowledged, and these comprised of Ia through Ib, II to VIII; novel IX serotype [13,25,26]. Genotyping on the basis of capsule is regarded as additional apposite for exploration of some epidemiological features due to the reason that serotypes are distinguished by means of or lacking the expression of CPS [7]. Alpha like protein (Alp) pedigree serves an imperative function for pathogenesis and pathology of $S$. agalactiae and as efficacious vaccine candidates [7,27]. The six associates of the Alp pedigree have been comprehensively researched, comprising of Rib, Alpha-CAlp1 $(\varepsilon), \alpha 2, \alpha 3$ and $\alpha 4$ [7], were encrypted by the genes bca, $\alpha 1(\varepsilon), \alpha 2 / 3$, Rib, then $\alpha 4$, correspondingly. The triad forms of the pili of $S$. agalactiae were classified which is labelled as pilus island-1, PI-2a\&b, of which PI- $2 a \& b$ encrypted with genes positioned on dual dissimilar loci on similar portion of the genomic DNA, however, the PI-1 gene is positioned on a discrete rsegment $[28,29]$. Another protein adhesive and anchorage termed hypervirulent adhesin ( $\mathrm{HvgA})$ is an HvgA gene that enables the progression of a molecular detection of isolates belonging to GBS ST-17. In a recent study [8] divulged that the following virulence genes PI-2b, fbsB, cfb, and hylB are enormously associated with the prevalence of mastitis in ruminants.

The physiognomies of several adjuvant of vaccine formulations which possess the capability of provoking collective immunity ensuing immunisation divulged that dendritic cells could perchance act as effective cell's molecule for presentation of antigen (APC) thus induces a collective immunology for the animal host, if the situations of microhabitant are aptly controlled subsequent to stimulation of the antigen. Substances such, as vitamin D3, organic boosters of cAMP and bacteriological toxins, all possess conjoint ability to prompt dendritic cell repositioning from the dermis to patches of Peyer's subsequent prompted progression to antigen $[30,31]$. Due to the constraints of breeding plans, as well as genomic assortment to increase resistance against pathogenic diseases comprising mastitis in ruminants', it is exigent to possess easily accessible and efficacious wide range, ideally proficiently offering defence for mastitis caused in ruminants' species thus decreasing disease transmission besides punctuating the prospective crossspecies spread to hominids [3].

For the clarification of the existing evolution in proteomics, metagenomics, metabolomics and transcriptomics exploration, an all-inclusive assessment of the enormous genes and proteins that were made known by a microorganism is highly accessible at present. However, it thus occurs a remarkable potentiality in these growing eras in understanding the bacterium and host relationship. For this reason, the prosperous facts could enormously pledge in development of most effective control measure for disease caused by $S$. agalactiae among hominids and faunas. Therefore, this periodical emphasis and elucidated regarding its standard, up-to-date procedures consisting of transcriptomics, proteomics, metabolomics, and metagenomics techniques and their importance on immunogenic responses of effective vaccine candidates against S. agalactiae in ruminants (Table 1 \& Figure 1 ).

\section{Adjuvants for the Delivery of S. Agalactiae Vaccine Candidates}

Severalclinicalresearches accomplished hitherto inoculated GBS conjugate vaccines utilize TT devoid of adjuvants [32]. A significant apprehension that intensified the usage of TT in humanoid is as a 
result of the foregoing immunity to the host apparently producing substantial inauspicious effects [32]. Additional protein CRM197 transporter verified vaccination trial in humanoid GBS formulation, which is a natural innocuous mutant of DT- diphtherial toxin and is obtained from C7 ( $\beta 197)$ - Corynebacterium diphtheriae isolates. It is an innocuous mutant of this toxin which varies from very virulent type toxin in a genetic change that eradicates action of enzymes and toxic tendencies. DT and CRM197 are antigenically identical, but CRM197 has ascendancy as a conjugate's protein; it is innocuous, providing as numerous lysyl side chains accessible for conjugation, indicating its supreme adaptability for conjugation to numerous polysaccharides in similar item. CRM-197 has being used in to formulating a glyco-conjugated GBS vaccines. CRM-V vaccine was inoculated into physically fit females for contrasting immunity acquired through immunization with formulation of TT$\mathrm{V}$. In $\mathrm{t} 2$ group inoculated with either TT-V or CRM-V, there was no significant statistical dissimilarity detected [33].

The prominence and a great value of vaccine formulations is to utilize a natural GBS proteins as transporters for CPS-conjugate. The alpha C protein and C5a-peptidase were efficaciously used as transporters for type-III CPS because of their capability of conferring fortification in animal against GBS infections [32,34]. These researches that were experimented on animals signify the evidence of the idea for the twofold prospective usage of natural GBS-protein serving 2 functions; transporter during production of CPS, and as vaccine's organism that can induce defensive immune responses. Previously, experiments indicating escalating immunity in baboons as well as in mice immunized with (GBS) type III - TT combined together to alum adjuvant [32].

\section{Induction of Multivalent B Cell Receptor Cross Linking by Prototype Polyclonal Capsular Polysaccharides}

The study of PS specific B cells are strictly tasking due to its very low quantity in the host. To evaluate the operationally cross linking of multivalent B-cells receptor, a proficient experimental polyclonal prototype PS mediation for B-cells receptor a reliant B-cells stimulation has been developed [35-37]. The prototype simulation was realized by covalently attaching numerous IgM or IgD mouse monocolonal antibodies to a heavy polysaccharide bond. This complex antibodies moity provoked strong production of a repose B-cells at levels that is e one-thousand-fold lesser comparative to bivalent antibodies moity (anti-Ig) [38]. It was because of the gathering of numerous membrane BCRs for effective signalling, and with negligible modification of BCR from the surface of the cell. The last mentioned permitted incessant signaling, because of the comparatively small amount of BCR molecules involved [38]. These findings were in accord with the studies reported by Snapper, (2016) [38] that at least 10 to 20 receptors Ig membrane is required for multivalent molecule of antigens for cross-linkage so that TImediated B-cells stimulation will ensue. [38] Snapper, (2016) explicated that using dextran combined IgD antibodies molecules ( $\alpha \delta$-dex), multivalent BCR cross linking, even though induces strong propagation of repose B cells was unsuccessful to provoke antibody extravasation [39]. Nevertheless, antibody extravasation was provoked on adding of IL 5 or IL 2 to cultured bacteria of $\alpha \delta$-dexstimulated B-cells. Subsequently analogous outcomes were gotten on evaluating experiment for TNPs-trinitrophenyl antibodies response against TI immunogen, and it has been suggested $\alpha \delta$-dex may perhaps obliges in-vitro prototype for TI infection outcome. A more orderly research of the operational out-turns of multivalent BCR cross linking utilising $\alpha \delta$-dex was carried out. The process of stimulation was contrasted and interceded by non-conjugated antiIg, lipopolysaccharide (LPS) from outer membrane [40,41] and CD40 ligands that manifested on CD4(+) T-cells thus attaches to CD40 onto the B-cells by attaching an equivalent receptor; TLR-4 (Toll-like receptor-4). The process of B cell stimulation evidently affected the effective responses of repose B-cells together with several TLR ligands and cytokines $[40,42,43]$.

\section{IgE Responses is Inhibited by Multivalent BCR Cross Linking}

Previous researches established the IL-4 stimulated switching of class in LPS-stimulated B cells to IgE and IgG1 has been observed [38]. Conversely, IL-4 similarly co-induced $\alpha \delta$-dex-stimulated B cells to shift to IgG1 and was unsuccessful in provoking noticeable response of IgE [38]. There was a correlation with the deficiency of germline or reorganized IgE specific RNA. Certainly, adding $\alpha \delta$ - dex into a B-cells stimulated interleukin 4-generating T-cells to prevent immunoglobulin E extravasation whereas increasing the generation of IgG1 and IgM $[38,44]$. IgE switching of class in LPS and IL-4 stimulated B cells was likewise particularly prevented via $\alpha \delta$-dex. Consequently, multivalent BCR cross linking vigorously overwhelms the transcription and consistently weighty $(\mathrm{CH})-\varepsilon$-gene [45], hence switching of IgE occurs. Subsequently cross-linkage of Ig-E onto surface of mast cells has been a powerful influencer of infection, ineffectiveness of multi-valent antigenic molecules that attaches to a specific antibody possessing a great proclivity for inducing Ig-E possibly will aid in host-defensive role [38].

\section{Class Switching for A 3-Signal Prototype of Ig}

The fusion of DNA with germ-line, transcription of heavy chains immunoglobulins genes was regarded as the prime contributing factors of immunoglobulin class switching [38]. Though, the fusion of $\alpha \delta$-dex+IL- 4 stimulated strong production and germline $\mathrm{CH} \gamma 1$ transcription but was not successful in stimulating switching to IgG1 except IL-5 is similarly available [38]. The fusion of DNA or the manifestation of germline $\mathrm{CH} \gamma 1$ is not transformed by IL-5. The combination of these occurrences led to the proposed three signal prototype of Ig class switching that forecasted some mechanisms of the Ig class switch contrivances which may perchance be substance of modulation [38].

In A $\delta$-Dex-Stimulated B Cells, IFN- $\gamma$ Promotes IgG2a and IgG3 Class Switching, and Similarly Stimulates Igm Extravasation

Interferon gamma (IFN- $\gamma$ ) stimulates IgG2a switching of class in LPS stimulated B cells, even though obstructing LPS stimulated 
substitution of IgG2b and IgG3 [38]. Stimulated CD4+ T cells releasing IFN- $\gamma$ likewise choosily stimulate IgG2a, even though not IgG3 release [38]. Nevertheless, IFN- $\gamma$ choosily stimulated IgG3 and IgG2a switching of class in $\alpha \delta$-dex and IL- 5 stimulated B cells, comprising of IFN and $\alpha \delta$-dex interceded stimulation of germ line Ig-G3 [38]. Little quantities present in germline Ig-G3 might likewise remain stimulated via $\alpha \delta$ - dex [38]. The studies are important given better stimulation of precise murine IgG3 responsiveness subsequent to vaccination with LPS [38]. Stimulation of IgG3 and IgG2a in vivo because of IFN- $\gamma$-generating $\mathrm{T}$ cells was detected [38]. Additionally, although IFN- $\gamma$ prevents IgM release by a lipopolysaccharide (LPS) or CD-40 stimulated B-cells, however the stimulated IgM responsiveness in B-cells stimulated $\alpha \delta$ - dex and IL 2 at the same time [38]. NK cells are plentiful resource of interferon- $\gamma$; stimulated throughout microbial contagions, likewise stimulated IgM extravasation into B-cells activated $\alpha \delta$ - dex and IL 2 [38], which is reliant on NK-cell generation of IFN $\gamma$ [38].

\section{IL-3 Stimulate Igm Release and in $A \delta$-Dex -Stimulated B Cells GM-CSF}

Besides IFN- $\gamma$, colony-inducing factors for instance GM-CSF and IL-3 are likewise secreted throughout microbial contagions. Remarkably, it was detected that GM-CSF and IL-3 might perchance similarly behave as B cell distinction factors, stimulating enormous quantity of released IgM, through exerting directly on greatly refined B-cells stimulated together of $\alpha \delta$-dex and IL 2, except CD-40 [38]. It was detected that B1 B cells, that are sturdily associated in TI responsiveness [38,46,47], particularly generate GM-CSF $[38,48]$. An imperative role for B-cells activation factors of the TNF families called BAFF and APRIL (A second ligand, a proliferation-inducing ligand), likewise manifested throughout microbial contagions to TI antigenic stimulant, inducing TI responsiveness [38,49].

Toll like receptors ligands similarly in combination with $\alpha \delta$ dex stimulated B cells stimulate Ig release; prototype aimed at TI stimulation of immunity via antibodies in response to microbes extracellularly [94]. Microbes, besides stimulating cytokines, can similarly perchance afford additional signal directed onto B-cells via manifestation of TLR-ligands. On utilization as vaccine adjuvants, CpG-ODNs increase the function of professional APC (antigen presenting cells) and enhance production of cellular and humoral specific vaccine's- immunity [50], CpG-ODN (TLR9) are all strong inducers of IgG and IgM generation in a $\alpha \delta$-dex stimulated B-cells at the amount of TLR ligand that singly stimulate minute antibody release [38]. As a whole, these advocated for a prototype of TI stimulation of humoral response of microbes extracellularly [38] (Figure 2 \& 3). Precisely, TLR ligands and cytokines manifested throughout contagions with PS enfold microbes extracellularly, might oblige as additional signals for humoral generation of B-cells stimulates via BCR multi-valent cross linkage (signal1) upon a response to manifested PS [38]. Besides, the capability of PS antigenic molecules to significantly enhance BCR reliant signal-1 via direct attachment of serum complements to the PS moity, or to PS-bound antibodies has been indicated [38,43,51]. Cross linking of BCR and the complement's receptors have combined effect for
B-cells stimulation to enhance antibody generation in animals $[38,52]$.

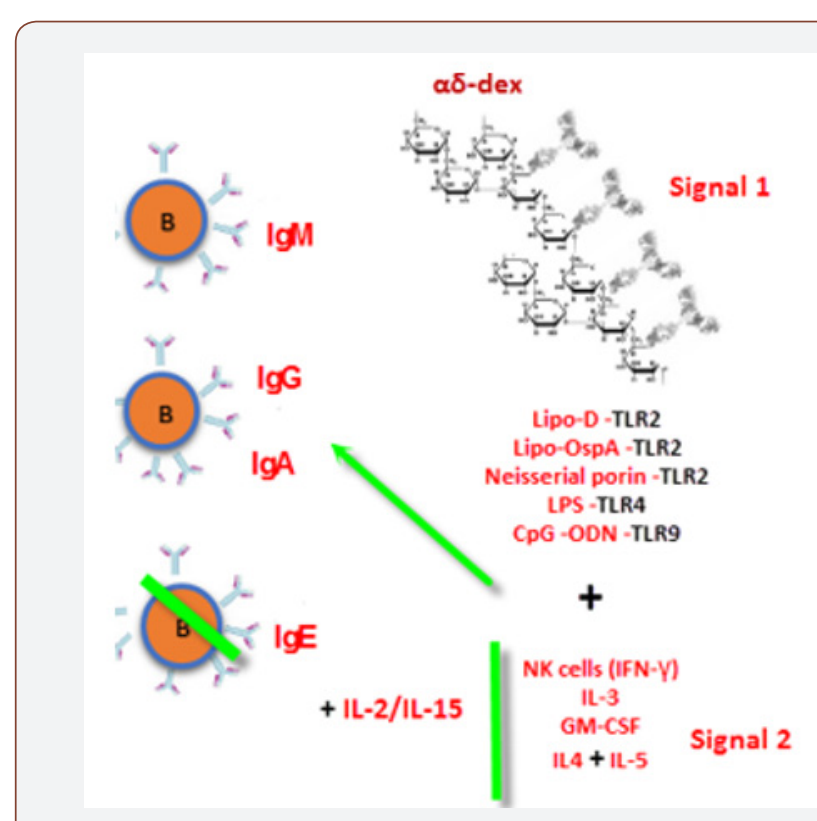

Figure 2: Anti Ig-dextran co-induces antibody extravasation and class switching in the present of cytokines and toll-like receptor ligands Sources: Snapper [35] with little modifications.

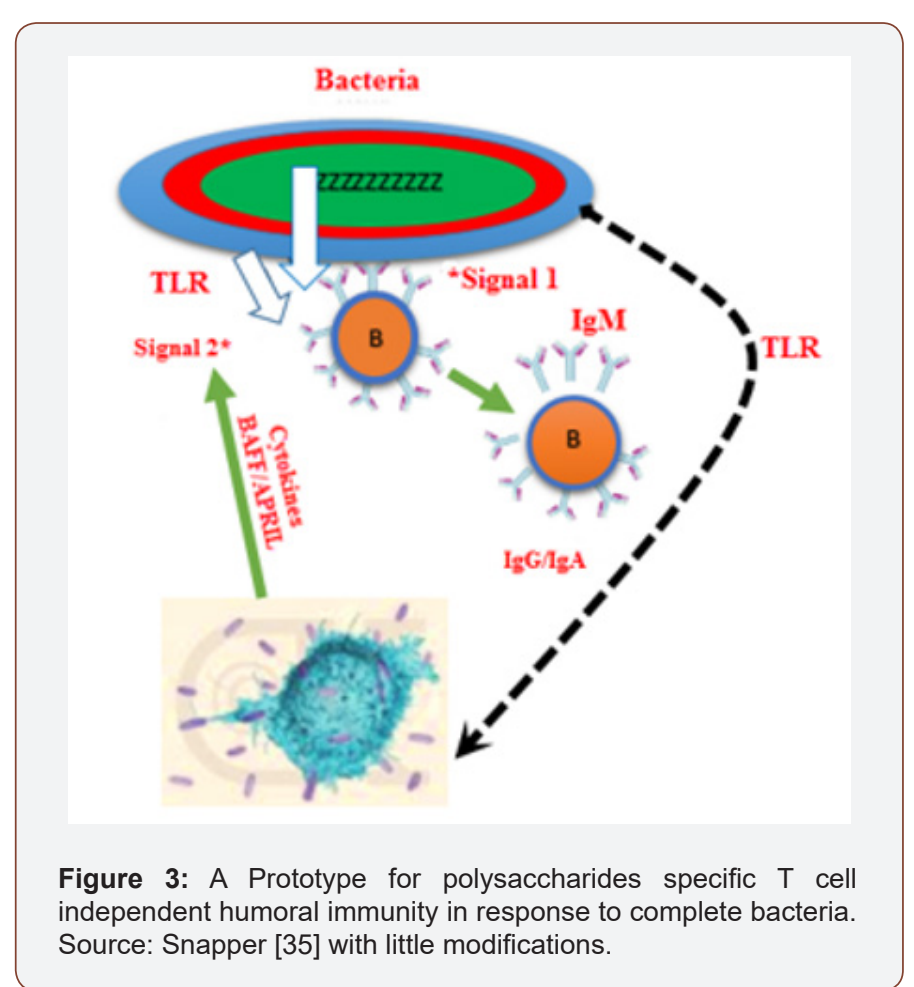

Capability of PS Extracted to Stimulate Antibody In Vivo Extravasation

Bacterial PS was extracted, comprising of approved PS vaccine, Pneumovax-23 (PPV-23), stimulate IgG and IgM activities in the older animals while inoculated singly in saline. These annotations apparently refuted the two-signal prototype for PS-stimulated antibody responses [38]. Nevertheless, as extracted PS are refined from microbes [53], the determination of availability of contamination of TLR ligands is responsible for PS-stimulated humoral immunity by affording additional indicators [38,42]. 
Undeniably, PS stimulated IL-6 extravasation of field isolate, nonetheless not TLR-2 macrophages, a feature, eliminated via phenol removal signifying lacking inherent attribute of PS [53]. There was a resultant forfeiture of IgG PS antibodies activities; likewise decreases in IgM PS antibodies activity compared to wildtype mice when vaccinated with TLR-2-/-mouse with bacterial PS. PPV-23 similarly stimulated IL-6 in field isolate of macrophages reliant on TLR-2 and TLR-4 ligands. Vaccination of mouse breed of the name "MyD88-/-mice" with PPV - 23 results in an analogous forfeiture of the IgG PS antiibodies, of which substantially decreases IgM anti-PS activity. Even though 7 - valent Streptococcal conjugate's vaccine; PCV7 (Prevnar-7) is a heptavalent vaccine, signifying that it comprises the cell capsule sugars of the 7 serotypes of S. pneumoniae (23F, 6B, 18C, 4, 9V, 14 and 19F), that have conjugation with the protein of diphtheria and immersed in aluminium phosphate adjuvant, which stimulates CD4+ TD antiPS activities, vaccination of TLR-2-/- mouse with PCV7 caused substantial decreases immunoglobulins (IgG3 and IgG2a) anti-PS activities, signifying contamination of TLR ligands which stimulates IFN- $\gamma$ in the mouse and amplified substituting to IgG2a and IgG3. Certainly, PCV7 stimulated IL- 6 of the field isolate however not TLR2-/- macrophages [38].

Furthermore, combining dissimilar TLR agonists for formulations of isolated bacterial PS heightened specific PS IgG and IgM activities $[38,54,55]$. CpG-ODN interceded the outcome on B-cells in a TI mode; similarly, heightened mouse specific hapten humoral activity of haptenated-Ficoll $[38,56]$. TLR-4 ligand (Monophosphoryl lipid A) heightened mouse humoral activity to PPV-23 [38]. Specific antibody activities were similarly induced an extra quantity of IL 2 to $1 \mathrm{~m}$ diameter liposome wrapped to bacteriological PS-molecule [38]. Worth mentioning, amplification of TI activities by TLR has been indicated for reliant upon TACI, APRIL's and BAFF's ligands [38,57]. Incidentally, TLR agonists induce APRIL and BAFF in myeloid cells, consequently, possibly enhancing their adjuvant influence for TI activities [38, 58-60].

\section{The Importance of TLR in TI Responses to Microbes Extracellularly}

Microbial TLR ligands can stimulate TI humoral immunity in microbes extracellularly. Vaccination of TLR2-/-, but not TLR4-/-mice with S. pneumoniae ensued substantial decrease in TI PS specific IgM response [38,61]. Even though, as primarily postulated, PS specific antibody activities of whole microbes would be principally $\mathrm{TI}$, however, the imperative functions of $\mathrm{CD} 4(+)$ T-cells is stimulating numerous features specific PS-IgG activities for Gram Positive as well as Gram Negative bacteria is glaringly obvious.

\section{The Importance of B Cell Receptor Signaling of PS against Protein Specific for Humoral Responses}

The programmed signalling activities interceded by BCR transverse linking, comprising of the significant function of Bruton's tyrosine kinase (Btk) was documented hitherto [38]. As antigens probably create masses in animal model and indication via the BCR, the differential prerequisite in lieu of BCR reliant Btk signalling interceding PS specific humoral activities versus protein were determined. Thus, it was documented that in the transgenic mice (Btklow) the manifestation of Btk was specifically decreased singly in B cells [38]. Inoculation of "Btklow mice" with S. pneumoniae ensued substantial decreases in specific PS IgG and IgM in addition to the phosphorylcholine (PC) determining factor onto C - polysaccharide, comparative with field's mice [38,62]. Comparing, IgG activity specific to bacterial surface protein A (PspA) was analogous amongst field isolate and Btklow mice [38]. Astonishingly, analogous substantial decreases in concentrations of specific IgG and IgM against PS and PC-, except PspA specific IgG activities were detected in Btklow mice in reaction to vaccination with conjugate's vaccine [38]. This information validates further noticeable function of whole BCR signalling in both TD PS and TI versus TD protein specific humoral activities. Additionally, faulty BCR signalling in "Btk-/- (x.i.d.) mice" results to a sternly decreased concentration of TACI in B-cells additionally affording insensitivity with antigens' of TI $[38,63]$.

\section{The Function of CD4+ T Cells Enhancing IgG Responses to PS Specific in Extracellular Microbes}

The essential mechanisms of PS specific humoral responses could change substantially when PS is manifested via bacteria for instance contrasted as if existing in the immune system of the host in isolation. Precisely, whole microorganisms collectively manifest PS and protein in a non-covalent mode, in a specific domain that has numerous NOD and TLR ligands. Manifestation of protein may well employ CD4 (+) T-cells that could enhance the PS antibodies'activity. Additionally, immunogenic tendency of antigens varies in certain instances contrasted to immunogens that are in dissolved form. For instance, comparative to dissolved antigens, have proclivity of concentrating in the peripheral region of spleen [38] and remain proficiently adopted by means of APC for heightening antigen manifestation [38,64]. Incidentally, a previous study detected a noticeable improvement in the PS specific humoral activity to whole, encapsulated bacteria comparative to cultivated dissolved bacterial PS [38]. Multivalent, however not divalent BCR cross linking coaction with CD40 interceded signalling in B cells to augment antibody extravasation and switching of class [38]. Discrete subcapsular regions of Gram-positive microbes may similarly present irreplaceable features that would control PS specific humoral activity. Thus, PS of Gram-positive microorganisms are covalently shared to peptidoglycan cell wall, to which numerous proteins are also covalently connected [65]. A study was carried out in mouse, to describe essential process of PS specific humoral responses in a whole Gram-positive extracellular bacterium. It was heat neutralized to precisely establish it property like composite immunogen. Extracellularly and Gram-positive bacteria include $S$. agalactiae; a GBS $[35,66,67]$. The information obtained from the study established a number of reliable dissimilarities amongst whole microbes as a whole as opposed to extracted PS; the IgG responses to PS manifested in whole microorganisms encompassed 
altogether the four mice IgG subclasses (IgG2a, IgG2b, IgG1, and IgG3) as opposed to the main IgG3, then slightly to IgG1 responses to extracted PS from whole microorganisms stimulated enormous titer, enhanced PS specific humoral responses following second vaccination, compared to extracted PS that was unable towards provoking increase lower level of responses; the production of specific IgG antibodies memory cells against PS in responses to whole microorganisms are consistently reliant on CD4 T-cells throughout the main vaccination. These physiognomies were analogous to the protein specific IgG responses stimulated by the microorganisms. Together, the IgM anti-PS responses to whole microbes were TI.

The strong CD4+ T-cells reliant (TD) PS specific IgG activities detected in whole microorganisms were the results of the conscription of CD4+ T-cells specific of the related protein of microorganisms. Discovering this likelihood, streamlined prototype for simulating whole S. pneumoniae was generated, in which bacterial PS and protein were individually covalently connected to the same $1 \mu \mathrm{m}$ thickness of fluid particles, however not covalently bound to one another [68]. Beads comprising of control of PS were choked to glycine to avert attachment of host's protein subsequent to vaccination. Inoculation of mouse with beads comprising of PS and the protein [69]. Additionally, mouse primarily primed with only protein, stimulated heightened specific IgG against PS after vaccination of PS or protein beads endorsing the significant function of the bacterial protein in the stimulation of the PS specific IgG response [68]. (Figure 4) represents the general summary of the factors that may affect specific antibody responses against PS and whole S. agalaciae.

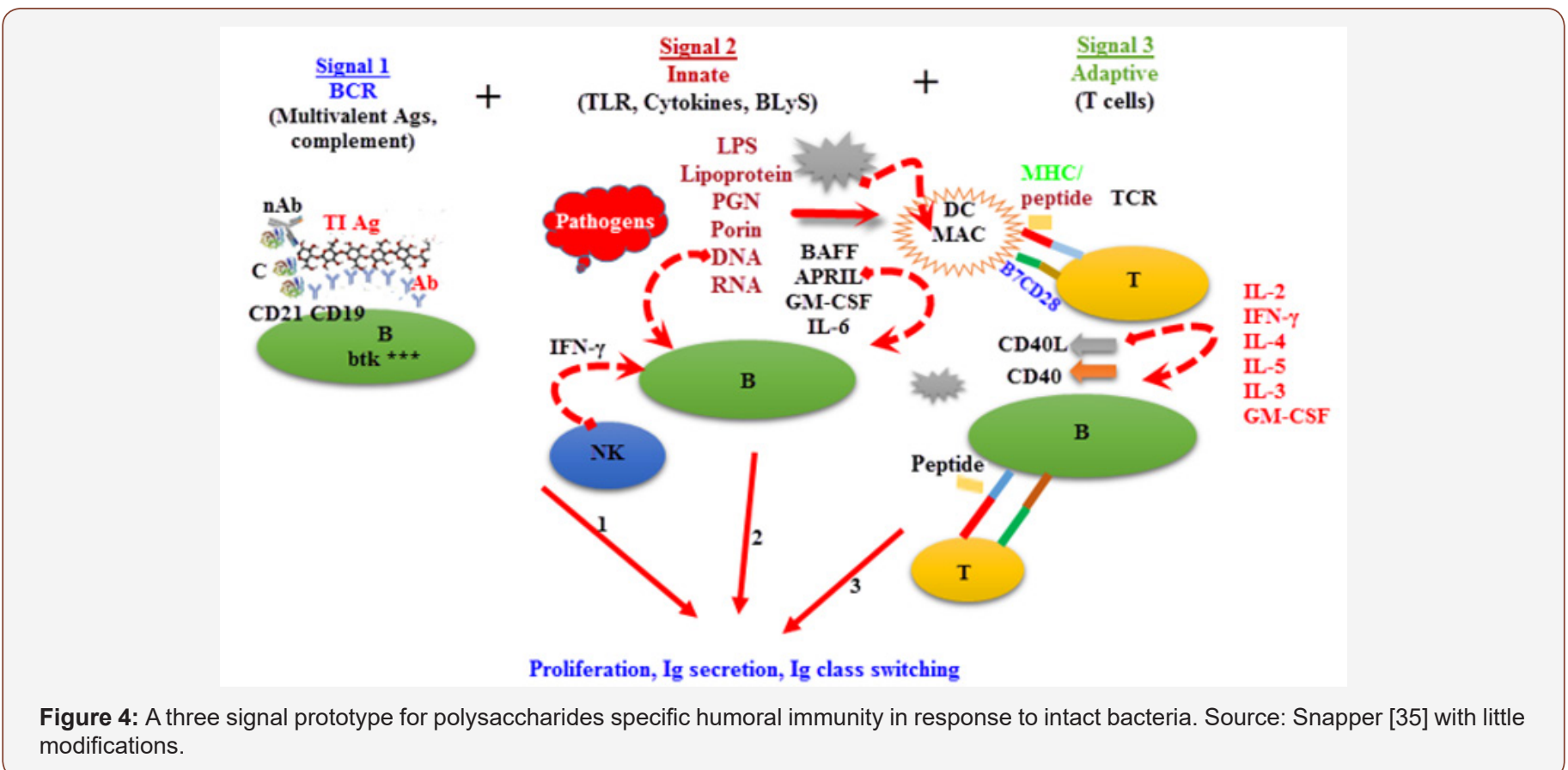

Specific Antibody Immunity to PS and GramPositive Extracellular Bacteria

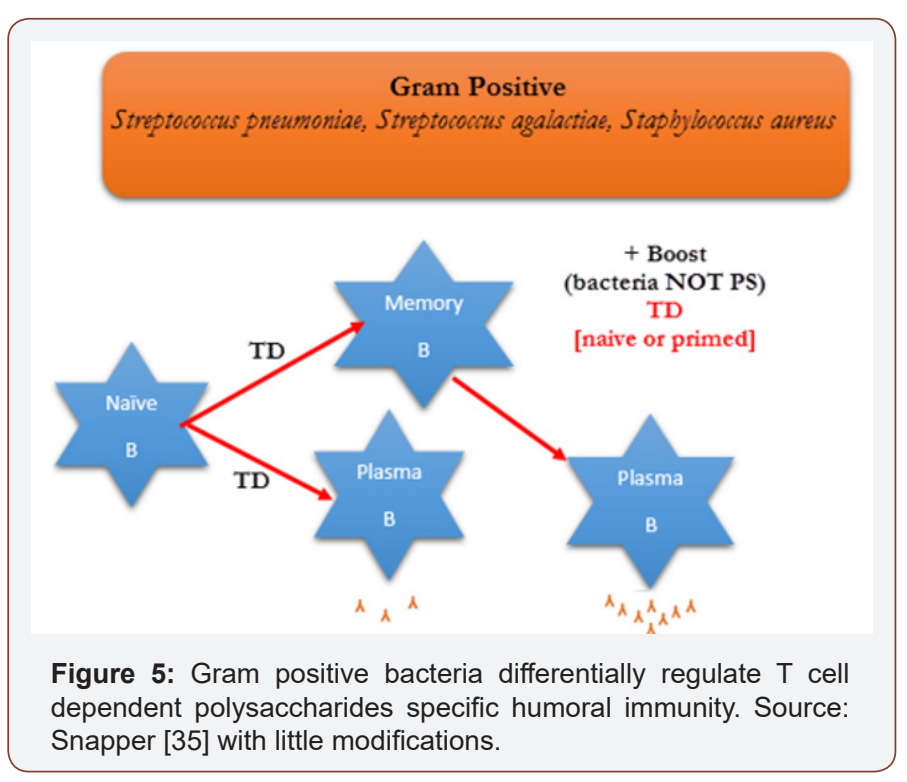

The specific IgG responses PS to Gram positive bacteria were reliant on $\mathrm{CD} 4+\mathrm{T}$-cells and peaked by day 7. Gram positive bacteria induced PS specific IgG memory that was reliant on CD4+ T cells throughout the initial vaccination [38]. Noticeable increase in serum PS specific IgG titers after second vaccination with whole microbes were detected for Gram positive bacteria. Reduction of CD4+ $\mathrm{T}$ cells at the time of second vaccination with Gram positive bacteria entirely abolished the increased PS specific IgG response. (Figure 5) depicted the details responses to PS to Gram-positive extracellular bacteria.

\section{PS Specific Humoral Responses to Whole Extracellular Microorganisms as Opposed to Conjugate Vaccines}

The resemblances amongst the regulation of specific IgG against PS response to complete microorganisms and PS protein conjugates vaccine were underscored [38], for stimulated PS specific IgG memory, dependent upon CD4 T-cells, which led to increase in PS specific IgG responses upon secondary vaccination were similarly elucidated. Nevertheless, it was found that some 
conspicuous dissimilarities amongst PS manifested superficially on whole microorganisms as opposed to the similar PS which is a constituent of this conjugated vaccine were noticeable. The Men-CPS booster considerably decreased regularity of freshly stimulated Men-C-PS specific B-cells frequently switch IgG1 memory B-cells by sending them into apoptotic process. It demonstrated reliably that apoptosis of specific memory cells PS, is the cause of PS stimulated hypo responsiveness [36]. Therefore, outcomes are usually considered before use of PS base vaccination.

\section{Vaccine Candidates against S. Agalactiae}

Some main proteins of $S$. agalactiae that are immunoreactive plays prospective task in the progression of vaccine against GBS disease [70]. Even though protein configurations detected for the sixty dissimilar GBS cultures divulged numerous resemblances, some modifications amongst serotypes were discerned. The four immunoreactive proteins existing are dehydrogenase, elongation factor $\mathrm{Tu}$, enolase, and trigger factor. Thus, this type of protein immunoreactivity similarly occurs amongst rat and human cytomegalovirus [71].

These proteins are present in the cytoplasm; they have their place on cell surface related proteins. Surface dehydrogenase and enolase had been designated as having multiple functional proteins of S. agalagiae [68]. Enolase, and its plasminogen attaching activities are implicated in occupation and attachment of bacteria to humanoid pharyngeal cells $[70,72]$. Streptococcus superficial enzyme (dehydrogenase); similarly, a pathogenic feature [70] is associated to GAPDH (glyceraldehyde-3-phosphate dehydrogenase).

It binds to fibronectin of mammalian or cytoskeletal proteins e.g. myosins and retains ADP-ribosylating actions [70]. It was revealed that Streptococcal surface related dehydrogenase identifies pharyngeal plasminogen activator receptor, which cause Streptococcal attachment thus contributes a significant function in pathogenesis/pathology $[70,72]$. The elongation factor Tu was detected on bacterial surface, and its conceivable role is attachment of bacteria to mammalian cells. Elongation factor (Tu) likewise found in the cytoplasm of the bacteria [70,72,75] therefore, proteins implicated in bacterial cell host collaboration throughout infection progression should be deliberated as vaccine choices for the control of S. agalaciae sequelae [74].

Classification of the prime external outer proteins of S. agalactiae, consisted of a proteomics exploration [75]. The unsheathing and detachment of the outer surface proteins by 2-D electrophoresis was carried out [75]. The envisaged specks were recognized by means of a mixture of peptide reverse genetic engineering and sequencing procedures. Among thirty main specks recognized as S. agalactiae specific, twenty-seven was acknowledged, 6 proteins, hitherto anonymous in S. agalactiae, were cloned and sequenced [75]. Comprising of nonphosphorylating glyceraldehyde-3phosphate dehydrogenase, ornithine carbamoyltransferase, purine nucleoside phosphorylase, glucose-6-phosphate isomerase, phosphoglycerate kinase, and enolase [75]. By means of a Grampositive expression vector, 2 out of the total proteins were overexpressed. Antisera were raised with these recombinant, purified proteins. The detection of the proteins existing on the cell wall boundaries was established due to capability of the antisera to reacts with the intact, active bacterium. Additionally, in neonate's prototype, it was established that some of the serum are defensive against harmful concentration of S. agalaciae. This study divulged prosperous usage of proteomic approaches as a contraption for recognizing the choice of vaccination for control measures [75], similar situations were reported in humans particularly in autism syndrome [76], complicated cases of otitis media associated with Streptococcus species [77] and dengue infections [78].

Manifestation of numerous surface antigens of Group B Streptococci (GBS) were labelled as R, X and c antigens [79]. $S$. agalactiae strain Compton $\mathrm{R}$ with a novel R-like surface protein was recognized by means of a polyclonal antiserum raised against the R protein portion of $S$. agalactiae strain. Exploration base on molecular analysis of positive clones permitted the extrapolation main feature of a 105 kilo Daltons ( $\mathrm{kDa}$ ) protein labelled as protein BPS; group B defensive outer protein that showed characteristic structures of Streptococcal outer proteins such as those responsible for membrane anchorage and signal sequence a zone nevertheless it doesn't indicate substantial resemblance with former recognized sequences [79].

Immunogold electron microscopy by means of a BPS specific antiserum established the surface position of BPS protein on $S$. agalactiae strain Compton R. Anti-BPS antibodies were not able to cross-react with R4 and R1 proteins manifested by two different type III GBS strains but reacted with the parental Streptococcal strain in Western blot and immunoprecipitation evaluations [79].

A multiplexing molecular technique has been established to describe prospective changeability within the sip gene from cattle isolates of $S$. agalactiae $[80,26]$. The imperfect sip gene called Ncosip was detected in 4 cultures of S. agalactiae [80]. Based on silico evaluation of the mislaid section of the amino acid arrangements, the N-tail (terminal) of the outer pathogenic proteins were observed to comprise a LysM zone pattern; whereas the imperfect gene was short of portion due of that pattern. Immune stimulation associated with Sip has been established through vaccination of mice and likewise the reaction is incompletely detected similarly with NcoSip [80]. In animal prototypes of $S$. agalactiae contagion the intravenous inoculation of the incompletely refined CAMP factor leads to the demise of rabbits [81] (Spellerberg, 2000), and the concurrent inoculation of refined CAMP-factor with sublethal dosages of $S$. agalactiae increases the mortality of mice [81].

Bioinformatics contraptions support numerous researchers in a broad spectrum of biological meadows [82-84]; absolutely, for the selection of a suitable vaccines of choice, analyses are certainly valued [82,85]. In a topical study, new multiepitope sub-unit vaccine; this consists of an assortment such as plentiful B-cell, IFN- $\gamma$ stimulating epitopes and T-cell, was made to stimulate 
a strong innate, as well as entire cellular and antibody responses as a hallmark reaction to the harmful bacterium encompassing the antimicrobial resistance infection(s). Presently, molecular dynamics (MD) replication is expansively exploited to get a betterquality intelligence of biological processes $[82,86]$. In the research of Nasim et al [82], MD replication approach has proven to discern the vaccine's activity and confirm stable relating to the binding molecular. The vaccine and receptor molecules were unfailing and thus, institute a premium methodology for interactions throughout the MD replication period [82].

Transcriptomics, Metabolomics, Proteomics and Metagenomics as promising procedures for the advancement of vaccines candidate against $S$. agalactiae in ruminants.

\section{Vaccines Approaches through Transcriptomics and Proteomics}

As an outcome of current advancement in transcriptomics and proteomics exploration, an extensive appraisal of the immeasurable proteins and genes that were revealed by a S. agalaciae is manageable. Proteomics, metabolomics and transcriptomics research were crucial development to varying genomic data regarding the action of proteins and cell's alteration. Wide-ranging genomic DNA of transcriptome research disclosed manifestation of virtually 70/100 of microbiological transcripts of gene $[87,88]$. Proteomics research concerning 1\&2-dimensional gel documented from mammalian and entomological tissue acquired through culturing procedures of microbes was about one-quarter from whole Open Reading Frames [88,89]. On the other hand, there were some prevailing complications in proteomic exploration with reference to bacteria; due to the remarkable effort encompassed in locating extremely refined specimen; presence of huge amount of host proteins reduces the capability of discerning and the responsiveness prominence of bacterial proteins [88,90]. The development of mass spectrometry (MS/MS nano-LC-MS/MS) based tandem proteomics in addition to the extremely responsive nano-liquid chromatography method augments protein estimation of microbes, by way of very small measures of proteins can be identified in specimens combined with a substantial measure of host proteins [88,91]. Transcriptomics and proteomic methods may perhaps be effective in evolving vaccine choices owing to their relative protein's abundance. Appraisal protein's expression, microorganisms can therefore aid in augmenting the understanding of the pathophysiology of microorganisms, and the convoluted swapping amongst microorganisms and its habitants, this increases some probabilities to assessment of new goals for a powerful immunogenic vaccine's primes for S. agalactiae.

\section{Vaccines Approaches through Metabolomics and Metagenomics}

These 2 latest approaches were upturn and perchance may well be propitious in identifying pathogenic particles of $S$. agalactiae as a suitable candidate for vaccination, transmitting ground-breaking vision for the development of potent vaccines. Investigation in metagenomics, and the research on microbes and their contribution to welfare and contagion may perhaps be immeasurably be intensified using this procedure. Metagenomics assessments are classically accomplished by sequencing a 16S \& 18 S bacterial rRNA (ribosomal RNA) or the sequencing of the intact metagenome shotgun, typically on an extremely similar pyro-sequencing podium $[83,87]$. The perception has lengthy the possibilities of culture reliant bacteriological methods which has boosted on the detail knowledge of bacterial units sticking at intestine, blood vessels, genitourinary tract skin and oral cavities and on how microbes interdepend on its hosts [88,92].

A wide-ranging meta-transcriptomic or metagenomic shot-gun (WMS), comprises the whole sequences of the bases (nucleotides) in a specimen, cataloguing microbes that might be present, viz strain or species pecking order whereas conveying hands-on based evidence on genomic content. Downsides of "WMS" comprise inflated economies of the base pair amount as well as funds required for estimation of the enormous information and contamination by host's nucleic acids. WMS techniques retain integral nucleic acids exclusion presumption as few microbes ruined glibly comparative to their counterpart. Therefore, it is best operative than NGS and Sangers denovo approaches; expertise which underpin less significant readings and thus persists to be liable to sequencing vagueness [88,93].

Eccentrically, metabolomics progressed as articulate, nonsubjective research of small molecular weight molecules, or metabolites, generated by the body in response to a biological stimulant. Metabolites are extravasated into body fluids by host and microbial cells, evaluated by mass spectrometry-based methods, and oriented alongside with collections of accredited biochemical. These procedures were involved to realize the mechanisms of pathogenesis and the uncovering of new-fangled biomarkers of disease. Metabolomics consistently stipulates the manifestation and the role of microbes living in difficult crannies and high speck diverse interconnection amongst microbes, host metabolism, and comparative welfare or contagion $[88,94]$.

Metabolites generated by microbial and host cells consist of unusual assortment of physicochemical features and may be present in all body tissues or fluids and are acquire in unrelated measures. Successively, no precise metabolomics podium can classify all metabolites in a specimen, accordingly unlike technique are recurrently employed $[88,95,96,97]$. NMR (Nuclear magnetic resonance) spectroscopy has not necessitate initial arrangement of elements from a specimen, conversely restrictive specimen formulation decreases the staying power; NMR can classically recognize elements at or above a milli-molar size. The main downsides of metabolomics studies are economically reliant, relation to extent of exertion required in the data valuation and data procurements. Moreover, an abundantly interpreted and an all-inclusive metabolite documentation, precisely for microbial acquire substances, is hitherto limited [88,97]. 


\section{Conflict of Interest}

This manuscript has not been submitted for publication elsewhere and been approved by all co-authors. The authors were hereby given a declaration that they do not have any conflict of interests during preparation of this manuscript.

\section{Acknowledgement}

Certainly, hereby we acknowledged the efforts of Encik Jefri M.N. and Encik Mohd-Fahmi Mashuri during the process of writing this manuscript.

\section{References}

1. Zdragas A, Tsakos P, Kotzamanidis C, Anatoliotis K, Tsaknakis I (2005) Outbreak of mastitis in ewes caused by Streptococcus agalactiae. J Hell Vet Med Soc 56(2): 114-121.

2. Pereira UP, Mian GF, Oliveira ICM, Benchetrit LC, Costa GM, Figueiredo, et al. (2010) Genotyping of Streptococcus agalactiae strains isolated from fish, human and cattle and their virulence potential in Nile tilapia. Vet Microbiol 140(1-2): 186-192.

3. Tiwari JG, Babra C, Tiwari HK, Williams V, Wet SD, et al. (2013) Trends in Therapeutic and Prevention Strategies for Management of Bovine Mastitis: An Overview. J Vaccines Vaccin 4: 176.

4. Cools P, Melin P (2017) Group B Streptococcus and perinatal mortality. Res Microbiol 168(9-10): 793-801.

5. Martinez G, Harel J, Higgins, R, Lacouture, S, Daignault D, et al. (2000) Characterization of Streptococcus agalactiae isolates of bovine and human origin by randomly amplified polymorphic DNA analysis. J clin microbiol 38(1): 71-78.

6. Guimarães JL, Brito MA, Lange CC, Silva MR, Ribeiro JB, et al. (2017) Estimate of the economic impact of mastitis: A case study in a Holstein dairy herd under tropical conditions. Prev Vet Med 142: 46-50.

7. Yang Y, Liu Y, Ding Y, Yi L, Ma Z, et al. (2013) Molecular Characterization of Streptococcus agalactiae Isolated from Bovine Mastitis in Eastern China. PLoS One 8(7): e67755.

8. Carvalho-Castro GA, Silva JR, Paiva LV, Custódio DA, Moreira RO, et al. (2017) Molecular epidemiology of Streptococcus agalactiae isolated from mastitis in Brazilian dairy herds. Braz J Microbiol 48(3): 551-559.

9. Zhao Z, Kong F, Martinez G, Zeng X, Gottschalk M, et al. (2006) Molecular serotype identification of Streptococcus agalactiae of bovine origin by multiplex PCR-based reverse line blot (mPCR/RLB) hybridization assay. FEMS Microbiol Lett 263(2): 236-239.

10. Down PM, Bradley AJ, Breen JE, Green MJ (2017) Factors affecting the cost-effectiveness of on-farm culture prior to the treatment of clinical mastitis in dairy cows. Prev Vet Med 145: 91-99.

11. Huijps K, Hogeveen H, Lam TJ, Lansink AG (2010) Costs and efficacy of management measures to improve udder health on Dutch dairy farms. J Dairy Sci 93(1): 115-124.

12. Keefe G (2012) Update on control of Staphylococcus aureus and Streptococcus agalactiae for management of mastitis. Vet Clin North Am Food Anim Pract 28(2): 203-216.

13. Johri AK, Paoletti LC, Glaser P, Dua M, Sharma PK, et al. (2006) Group B Streptococcus: global incidence and vaccine development. Nat. Rev. Microbiol 4(12): 932-942.

14. Amal MN, Zamri-Saad M, Siti-Zahrah A, Zulkafli AR, Nur-Nazifah M (2013) Molecular characterization of Streptococcus agalactiae strains isolated from fishes in Malaysia. J Appl Microbiol 115(1): 20-29.

15. Xuzhuang S, Teresa L, Yonghong Y, Marianne L, Margareta F, et al. (2000) Systemic and Mucosal Immune Responses in Mice after Mucosal Immunization with Group B Streptococcus Type III Capsular Polysaccharide-Cholera Toxin B Subunit Conjugate Vaccine. Infect Immun 68(10): 5749-5755.

16. Jennifer L Gommerman, O Rojas L, Jörg HF (2014) Re-thinking the functions of IgA+ plasma cells. Gut Microbes 5(5): 652-662.
17. Patras KA, Rösler B, Thoman ML, Doran KS (2015) Characterization of host immunity during persistent vaginal colonization by Group B Streptococcus. Mucosal Immunol 8(6): 1339-48.

18. Baker JA, Lewis EL, Byland LM, Bonakdar M, Randis TM, et al. (2017) Mucosal vaccination promotes clearance of Streptococcus agalactiae vaginal colonization. Vaccine 35(9): 1273-1280.

19. Gherardi G, Imperi M, Baldassarri L, Pataracchia M, Alfarone G, et al. (2007) Molecular epidemiology and distribution of serotypes, surface proteins, and antibiotic resistance among group B Streptococci in Italy. J Clin Microbiol 45(9): 2909-2916.

20. Manning SD, Springman AC, Million AD, Milton NR, McNamara SE, et al. (2010) Association of Group B Streptococcus Colonization and Bovine Exposure: A Prospective Cross-Sectional Cohort Study. PLoS ONE 5(1): e8795.

21. Jones N, Bohnsack JF, Takahashi S, Oliver KA, Chan MS, et al. (2003) Multilocus sequence typing system for group B Streptococcus. J Clin Microbiol 41(6): 2530-2536.

22. Oliveira ICM, De Mattos MC, Pinto TA, Ferreira Carvalho BT, Benchetrit LC, et al. (2006) Genetic relatedness between group B Streptococci originating from bovine mastitis and a human group B Streptococcus Type $\mathrm{V}$ cluster displaying an identical pulsed-field gel electrophoresis pattern. Clin Microbiol Infect 12(9): 887-893.

23. Dogan B, Schukken YH, Santisteban C, Boor KJ (2005) Distribution of serotypes and antimicrobial resistance genes among Streptococcus agalactiae isolates from bovine and human hosts. J Clin Microbiol 43(12): 5899-5906.j

24. Slotved HC, Kong F, Lambertsen L, Sauer S, Gilbert GL (2007) Serotype IX, a proposed new Streptococcus agalactiae serotype. J Clin Microbiol 45(9): 2929-2936.

25. Gilbert GL (2004) Vaccines for other neonatal infections: are group B Streptococcal infections vaccine-preventable? Expert Rev Vaccines 3(4): 371-374.

26. Rosini R, Rinaudo CD, Soriani M, Lauer P, Mora M, et al. (2006) Identification of novel genomic islands coding for antigenic pilus-like structures in Streptococcus agalactiae. Mol Microbiol 61(1): 126-141.

27. Enioutina EY, Visic DM, Daynes RA (2000) Enhancement of common mucosal immunity in aged mice following their supplementation with various antioxidants. Vaccine 18: 2381-2393.

28. Lawan A, Jesse FFA, Idris UH, Odhah MN, Arsalan M, et al. (2018) Mucosal and systemic responses of immunogenic vaccines candidates against enteric Escherichia coli infections in ruminants: A review. Microb Pathog 117: $175-183$.

29. Nuccitelli A, Rinaudo CD, Maione D (2015) Group B Streptococcus vaccine: state of the art. Ther Adv Vaccines 3: 76-90.

30. Baker CJ, Paoletti LC, Rench MA, Guttormsen HK, Edwards MS, et al. (2004) Immune response of healthy women to 2 different group B Streptococcal type V capsular polysaccharide-protein conjugate vaccines. J Infect Dis 189(6): 1103-1112.

31. Cheng Q Stafslien D, Purushothaman SS, Cleary P (2002) The group B Streptococcal C5a peptidase is both a specific protease and an invasin. Infect Immun 70: 2408-2413.

32. Brunswick M, Finkelman FD, Highet PF, Inman JK, Dintzis HM, et al. (1988) Picogram quantities of anti-Ig antibodies coupled to dextran induce B cell proliferation. J Immunol 140(10): 3364-3372.

33. Brynjolfsson SF, Henneken M, Bjarnarson SP, Mori E, Del Giudice G, et al. (2011) Hyporesponsiveness Following Booster Immunization with Bacterial Polysaccharides Is Caused by Apoptosis of Memory B Cells. J Infect Dis 205: 422-430.

34. Snapper CM (2006) Differential regulation of protein- and polysaccharide-specific Ig isotype production in vivo in response to whole S. pneumoniae. Curr Protein Pept Sci 7: 295-305.

35. Snapper CM (2016) Differential regulation of polysaccharide-specific antibody responses to isolated polysaccharides, conjugate vaccines, and whole Gram-positive versus Gram-negative extracellular bacteria. Vaccine 34(30): 3542-3548. 
36. Pecanha LM, Snapper CM, Finkelman FD, Mond JJ (1991) Dextranconjugated anti-Ig antibodies as a model for T cell-independent type 2 antigen-mediated stimulation of Ig secretion in vitro. I. Lymphokine dependence. J Immunol 146: 833-839.

37. Ali OS, Adamu L, Abdullah FFJ, Abba Y, Hamzah HB, et al. (2015) Haematological and Histopathological Vicissitudes Following Oral Inoculation of Graded Doses of Pasteurella multocida Type B: 2 and its Lipopolysaccharide in Mice. J Veterinar Sci Technol 6: 220.

38. Faez F, Omar SA, Lawan A, Yusuf A, Hazilawati BH, et al. (2014) Modifications in serum Amyloid A and Haptoglobin in mice following oral inoculation of graded doses of P. multocida type B: 2 and its lipopolysaccharide. ROAVS 4 (11): 587-592.

39. Sen G, Khan AQ, Chen Q Snapper CM (2005) In vivo humoral immune responses to isolated bacterial polysaccharides are dependent on the presence of associated TLR ligands. J Immunol 175(5): 3084-3091.

40. Calzas C, Goyette Desjardins G, Lemire P, Gagnon F, Lachance C, et al. (2013) Group B Streptococcus and Streptococcus suis Capsular Polysaccharides Induce Chemokine Production by Dendritic Cells via Toll-Like Receptor 2- and MyD88-Dependent and -Independent Pathways. Infect Immun 81: 3106-3118.

41. Peçanha LM, Yamaguchi H, Lees A, Noelle RJ, Mond JJ, et al. (1993) Dextran conjugated anti-IgD antibodies inhibit $\mathrm{T}$ cell-mediated IgE production but augment the synthesis of IgM and IgG. J Immunol 150: 2160-2168.

42. Cvekl A, Zheng D (2009) Gene sharing and evolution. Hum Genomics 4: 66-67.

43. Alugupalli KR, Leong JM, Woodland RT, Muramatsu M, Honjo T, et al. (2004) B1b lymphocytes confer $\mathrm{T}$ cell-independent long-lasting immunity. Immunity 21: 379-390.

44. Haas KM, Poe JC, Steeber DA, Tedder TF (2005) B-1a and B-1b cells exhibit distinct developmental requirements and have unique functional roles in innate and adaptive immunity to S. pneumoniae. Immunity 23 : 7-18.

45. Rauch PJ, Chudnovskiy A, Robbins CS, Weber GF, Etzrodt M, et al. (2012) Innate response activator $\mathrm{B}$ cells protect against microbial sepsis. Science 335: 597-601.

46. Castigli E, Wilson SA, Scott S, Dedeoglu F, Xu S, et al. (2005) TACI and BAFF-R mediate isotype switching in B cells. J Exp Med 201: 35-39.

47. Bode C, Zhao G, Steinhagen F, Kinjo T, Klinman DM, et al. (2011) CpG DNA as a vaccine adjuvant. Expert Rev Vaccines 10: 499-511.

48. Dimitrov JD, Planchais C, Roumenina LT, Vassilev TL, Kaveri SV, et al. (2013) Antibody polyreactivity in health and disease: statu variabilis. J Immunol 191: 993-999.

49. Test ST, Mitsuyoshi J, Connolly CC, Lucas AH, (2001) Increased immunogenicity and induction of class switching by conjugation of complement $\mathrm{C} 3 \mathrm{~d}$ to bacterial serotype 14 capsular polysaccharide. Infect Immun 69: 3031-3040.

50. Ali OS, Adamu L, Abdullah FFJ, Ilyasu Y, Abba Y, et al. (2015) Alterations in Interleukin-1 $\beta$ and Interleukin- 6 in Mice Inoculated Through the Oral Routes Using Graded Doses of P. Multocida Type b: 2 and its Lipopolysaccharide Ajavs 10: 1-8.

51. Taillardet M, Haffar G, Mondière P, Asensio MJ, Gheit H, et al. (2009) The thymus-independent immunity conferred by a bacterial polysaccharide is mediated by long-lived plasma cells. Blood 114: 4432-4440.

52. Taillardet M, Haffar G, Mondière P, Asensio MJ, Pléau-Pison T, et al. (2010) Toll-like receptor agonists allow generation of long-lasting antibacterial humoral immunity in response to a plain polysaccharidic vaccine. J Infect Dis 202: 470-479.

53. Kovarik J, Bozzotti P, Tougne C, Davis HL, Lambert PH, et al. (2001) Adjuvant effects of $\mathrm{CpG}$ oligodeoxynucleotides on responses against T-independent type 2 antigens. Immunology 102: 67-76.

54. Ozcan E, Garibyan L, Lee JJ, Bram RJ, Lam KP, et al. (2009) Transmembrane activator, calcium modulator, and cyclophilin ligand interactor drives plasma cell differentiation in LPS-activated B cells. J Allergy Clin Immunol 123: 1277-1286.
55. Boulé MW, Broughton C, Mackay F, Akira S, Marshak-Rothstein A, et al. (2004) Toll-like receptor 9-dependent and -independent dendritic cell activation by chromatin-immunoglobulin G complexes. J Exp Med 199: 1631-1640.

56. Craxton A, Magaletti D, Ryan EJ, Clark EA (2003) Macrophage- and dendritic cell-dependent regulation of human B-cell proliferation requires the TNF family ligand BAFF. Blood 101: 4464-4471.

57. Nardelli B, Belvedere O, Roschke V, Moore PA, Olsen HS, et al. (2001) Synthesis and release of B-lymphocyte stimulator from myeloid cells. Blood 97: 198-204.

58. Khan AQ, Chen Q Wu ZQ, Paton JC, Snapper CM, et al. (2005) Both innate immunity and type 1 humoral immunity to Streptococcus pneumoniae are mediated by MyD88 but differ in their relative levels of dependence on toll-like receptor 2. Infect Immun 73: 298-307.

59. Khan AQ, Sen G, Guo S, Witte ON, Snapper CM, et al. (2006) Induction of in vivo antipolysaccharide immunoglobulin responses to whole Streptococcus pneumoniae is more heavily dependent on Btk-mediated B-cell receptor signalling than antiprotein responses. Infect Immun 74: 1419-1424.

60. Uslu K, Coleman AS, Allman WR, Katsenelson N, Bram RJ, et al. (2014) Impaired B cell receptor signalling is responsible for reduced TACI expression and function in X-linked immunodeficient mice. J Immunol 192: 3582-3595.

61. Colino J, Chattopadhyay G, Sen G, Chen Q Lees A, et al. (2009) Parameters underlying distinct $\mathrm{T}$ cell-dependent polysaccharide-specific IgG responses to a whole gram-positive bacterium versus a soluble conjugate vaccine. J Immunol 183: 1551-1559.

62. Jedrzejas MJ (2004) Extracellular virulence factors of Streptococcus pneumoniae. Front Biosci 9: 891-914.

63. Snapper CM (2012) Mechanisms underlying in vivo polysaccharidespecific immunoglobulin responses to whole extracellular bacteria. Ann N Y Acad Sci 1253: 92-101.

64. Arjunaraja S, Paoletti LC, Snapper CM (2012) Structurally identical capsular polysaccharide expressed by whole group B S. ococcus versus Streptococcus pneumoniae elicits distinct murine polysaccharidespecific IgG responses invivo. J Immunol 188: 5238-5246.

65. Colino J, Duke L, Snapper CM (2013) Noncovalent association of protein and capsular polysaccharide on bacteria-sized latex beads as a model for polysaccharide-specific humoral immunity to whole gram-positive extracellular bacteria. J Immunol 191: 3254-3263.

66. Simpson TR, Quezada SA, Allison JP (2010) Regulation of CD4 T cell activation and effector function by inducible costimulatory (ICOS). Curr Opin Immunol 22(3): 326-332.

67. Brzychczy-Wloch M, Gorska S, Brzozowska E, Gamian A, Bulanda $M$ et al. (2013) Identification of high immunoreactive proteins from Streptococcus agalactiae isolates recognized by human serum antibodies. FEMS Microbiol Lett 349(1): 61-70.

68. Camalxaman SN, Zeenathul NA, Quah YW, Loh HS, Zuridah H, et al. (2011) Cross-reactivity of Malaysian rat cytomegalovirus strains with its human counterpart. Trop Biomed 28(3): 661-667.

69. Severin A, Nickbarg E, Wooters J, Quazi SA, Matsuka YV, et al. (2007) Olmsted SB. Proteomic analysis and identification of Streptococcus pyogenes surface-associated proteins. J Bacteriol 189(5): 1514-1522.

70. Kolberg J, Hammerschmidt S, Frank R, Jonák J, Šanderová H, et al. (2008) The surface-associated elongation factor Tu is concealed for antibody binding on viable pneumococci and meningococci. FEMS Immunol Med Microbiol 53(2): 222-230.

71. Sharma P, Lata H, Arya DK, Kashyap AK, Kumar H, et al. (2013) Role of pilus proteins in adherence and invasion of Streptococcus agalactiae to the lung and cervical epithelial cells. J Biol Chem 288(6): 4023-4034.

72. Hughes MJ, Moore JC, Lane JD, Wilson R, Pribul PK, et al. (2002) Identification of major outer surface proteins of Streptococcus agalactiae. Infect immun 70(3): 1254-1259.

73. Erdogan S, Fagan PK, Talay SR, Rohde M, Ferrieri P, et al. (2002) Molecular Analysis of Group B Protective Surface Protein, a New Cell

Citation: Lawan A, Jesse FFA, Odhah MN, Bala JA, Arsalan M, etal. Immunogenic Responses of Effective Vaccine Candidates against Streptococcus 
Surface Protective Antigen of Group B Streptococci. Infect Immun 70(2): 803-811.

74. Vidova B, Chotar M, Godany A (2009) N-Terminal Anchor in Surface Immunogenic Protein of Streptococcus agalactiae and Its Influence on Immunity Elicitation. Folia Microbiol 54(2): 161-166.

75. Spellerberg B (2000) Pathogenesis of neonatal Streptococcus agalactiae infections. Microbes Infect 2(14): 1733-1742.

76. Hajighahramani N, Nezafat N, Eslami M, Negahdaripour M, Rahmatabadi SS, et al. (2017) Immunoinformatics analysis and in silico designing of a novel multi-epitope peptide vaccine against Staphylococcus aureus. Infect Genet Evol 48: 83-94.

77. Negahdaripour M, Nezafat N, Ghasemi Y (2016) A panoramic review and in silico analysis of IL-11 structure and function. Cytokine Growth Factor Rev 32: 41-61.

78. Rahmatabadi SS, Nezafat N, Negahdaripour M, Hajighahramani N, Morowvat MH, et al. (2016) Studying the features of 57 confirmed CRISPR loci in 29 strains of Escherichia coli. J Basic Microbiol 56(6): 645-653.

79. Zagursky RJ, Olmsted SB, Russell DP, Wooters JL (2003) Bioinformatics: how it is being used to identify bacterial vaccine candidates. Expert Rev. Vaccines 2(3): 417-436.

80. Hansson T, Oostenbrink C, Van Gunsteren W (2002) Molecular dynamics simulations. Curr Opin Struct Biol 12: 190-196.

81. Nelson CM, Herron MJ, Felsheim RF, Schloeder BR, Grindle SM, et al. (2008) Whole genome transcription profiling of Anaplasma phagocytophilum in human and tick host cells by tiling array analysis. BMC Genomics 9: 364

82. Adamu L, Turaki UA, Bukar-Kolo YM, Husainy AY, Dauda I, et al (2016) Current updates on diagnostic methodologies for tick-borne hemoparasitic diseases in equids: A review. JAVAR 3(2): 84-91.

83. Seo GM, Cheng C, Tomich J, Ganta RR (2008) Total, membrane, and immunogenic proteomes of macrophage- and tick cell-derived Ehrlichia chaffeensis evaluated by liquid chromatography-tandem mass spectrometry and MALDI-TOF methods. Infect Immun 76(11): 48234832.

84. Li Q, Lostumbo G (2010) Proteomic analyses of a variety of intracellular bacterial species infecting different host cell lines. Curr Proteomics 83(7): 222-232.
85. Zimmer JS, Monroe ME, Qian WJ, Smith RD (2006) Advances in proteomics data analysis and display using an accurate mass and time tag approach. Mass Spectrom Rev 25(3): 450-482.

86. Dave M, Higgins PD, Middha S, Rioux KP (2012) The human gut microbiome: current knowledge, challenges, and future directions. Translational Research: J Lab Clin Med 160(4): 246-257.

87. Morgan XC, Huttenhower C (2014) Metaomic analytic techniques for studying the intestinal microbiome. Gastroenterology 146(6): 14371448.

88. García-Álvarez L, Holden MT, Lindsay H, Webb CR, Brown DF, et al. (2011) Methicillin-resistant Staphylococcus aureus with a novel mecA homologue in human and bovine populations in the UK and Denmark: a descriptive study. Lancet Infect Dis 11(8): 595-603.

89. Dettmer K, Aronov PA, Hammock BD (2007) Mass spectrometry-based metabolomics. Mass Spectrom Rev 26(1): 51-78.

90. Yozwiak NL, Skewes-Cox P, Stenglein MD, Balmaseda A, Harris E, et al. (2012) Virus identification in unknown tropical febrile illness cases using deep sequencing. PLOS Negl Trop Dis 6: e1485.

91. Preidis GA, Hotez, PJ, (2015) The Newest "Omics"-Metagenomics and Metabolomics-Enter the Battle against the Neglected Tropical Diseases. PLOS Negl Trop Dis 9: e0003382.

92. Bishi DK, Verghese S, Verma RS (2008) Molecular typing of colonizing Streptococcus agalactiae strains by enterobacterial repetitive intergenic consensus PCR (ERIC-PCR) in a Chennai based hospital. Indian J Microbiol 48(2): 291-296.

93. Khodaei F, Najafi M, Hasani A, Kalantar E, Sharifi E, et al. (2018) Pilusencoding islets in $S$. agalactiae and its association with antibacterial resistance and serotype distribution. Microb Pathog 116: 189-194.

94. Zamri-Saad M, Effendy AWM, Israf DA, Azmi ML (1999) Cellular and humoral responses in the respiratory tract of goats following intranasal stimulation using formalin-killed Pasteurella haemolytica A2. Vet Microbiol 65(3): 233-240.

95. Aliyu IA, Bala JA, Maqsood M (2016) Autism, Surge in the Prevalence and Linkage with Childhood Vaccination - A Review. Bay J Med Lab Sci 1(1): 14-25.

96. Aliyu IA, Kumurya AS, Bala, JA, John OC (2017) Bacteriology of Otitis Media and Its Host-Environmental-Infection Factors. APEOHJ 3(1).

97. Suppiah J, Sakinah S, Chan SY, Wong, YP, Bala JA, et al. (2018) Platelet Transcriptome-Based Approaches in the Fight against Dengue Infections and Other Diseases. Pertanika J Sci Technol 27. 